\title{
FOOD WASTE AND FOOD LOSS IN THE RETAIL SUPPLY CHAIN
}

\section{Kristina Petljak}

\begin{abstract}
The food supply chain consists of five phases: production, storage and handling, processing and packaging, distribution on the market, and final consumption. Appropriate conditions need to be provided at each stage of the supply chain to reduce food losses and food waste. A fundamental transformation of the global food system is needed in order to tackle food waste and food loss. The growing attention to food loss and waste is reflected in the UN Sustainable Development Goals (SDGs), SDG 12: Responsible Consumption and Production (UN SDG, 2015,) and food loss and food waste are highlighted in the European Green Deal (2019) and Farm to Fork Strategy. This paper aims to determine the reasons for the generation of food waste in the retail supply chain. The purpose of this paper is to identify and provide the current status of the food waste and food loss research in the retail supply chain, based on the analysis of the available secondary literature.
\end{abstract}

KEYWORDS: food waste, food loss, food supply chain management, food retail supply chain.

\section{INTRODUCTION}

Future challenges to the global food supply chain are complex ${ }^{1}$ and due to that, companies should change their management practices towards more efficient resource use. ${ }^{2}$ Global food demand is driven by population and econom-

Kristina Petljak, Faculty of Economics and Business, University of Zagreb, Zagreb, Croatia; kpetljak@efzg.hr.

1 Derqui, B., Fayos, T., Fernandez, V.: Towards a More Sustainable Food Supply Chain: Opening up Invisible Waste in Food Service, Sustainability, 8 (7) 2016, pp. 1-20.

2 Vanham, D., Bouraoui, F., Leip, A., Grizzetti, B., Bidoglio, G.: Lost water and nitrogen resources due to EU consumer food waste. Environmental Research Letters, 10 (8) 2015, pp. 1-15. 
ic growth, and urbanization. One important measure to meet this increasing demand and to decrease the pressure on food production is to minimize food losses and food waste. The term food waste follows the definition of Food and Agriculture Organization of the United Nations (FAO) ${ }^{3}$ as the "removal of food from the supply chain which is fit for consumption, or which has spoiled or expired, mainly caused by economic behavior, poor stock management or neglect". In addition to this, FAO addresses the food loss as loss which occurs "in the production and distribution segments of the food supply chain and is mainly caused by the functioning of the food production and supply system or its institutional and legal framework". Food waste and food loss are major societal, economic, nutritional, and environmental challenges. ${ }^{4}$

Global food demand is expected to rise over the coming decades, reaching a 60 percent increase over the total current demand for food by 2050.5 As such, awareness of food losses and food waste has grown at the international level. The 'Sustainable Development Goals' (SDG) agreed in 2015 identify food waste and food loss as important challenges for achieving sustainable consumption, and Goal 12.3 aims to "By 2030, halve per capita global food waste at the retail and consumer levels and reduce food losses along production and supply chains, including post-harvest losses". ${ }^{6}$ Food loss and food waste are also highlighted in the European Green Deal ${ }^{7}$ and Farm to Fork Strategy ${ }^{8}$.

\section{FOOD LOSS AND FOOD WASTE IN THE SUPPLY CHAIN}

Food loss and waste occur at every stage of the supply chain, from production to consumption (Figure 1). At the production stage, important causes of infarm losses include inadequate harvesting time, climatic conditions, practices

FAO (2014) Food balance sheets. Available at: http://faostat3.fao.org/faostatgateway/go/to/ download/FB/*/E (accessed 10 September 2021).

4 Scherhaufer, S., Moates, G., Hartikainen, H., Waldron, K., Obersteiner, G.: Environmental impacts offood waste in Europe, Waste Management, 77 (July) 2018, pp. 98-113.

5 Alexandratos, N., Bruinsma, J. (2012) WORLD AGRICULTURE TOWARDS 2030/2050 - The 2020 Revision, Available at: http://www.fao.org/3/a-ap106e.pdf (accessed 10 September 2021).

6 UNEP (2015) Sustainable Development Goals. Available online at: http://www.undp. org/ content/dam/undp/library/corporate/brochure/SDGs_Booklet_Web_En.pdf, (accessed 10 September 2021).

7 European Green Deal (2019) Available online at: https://ec.europa.eu/info/strategy/priorities-2019-2024/european-green-deal/delivering-european-green-deal_en (accessed 10 September 2021).

8 Farm to Fork Strategy (2019) Available online at: https://ec.europa.eu/food/horizontal-topics/farm-fork-strategy_en (accessed 10 September 2021). 
applied at harvest and handling, and challenges in marketing produce. At storage, significant losses are caused by inadequate storage, as well as decisions made at earlier stages of the supply chain that cause products to have a shorter shelf-life.

In transit, losses occur due to the lack of proper infrastructure and efficient trade logistics. At processing/manufacturing and packaging levels, losses are often caused by inadequate facilities, technical malfunction, human effort, or inappropriate packaging (failures in sealing, filling process).

At the distribution and market stage, food is wasted due to the limited shelf life, the need for food products to meet the aesthetic standards in terms of color, shape, and size, and variability in demand. At the consumption stage, waste is often caused by poor purchase and meal planning excess buying (influenced by over-large portioning and package sizes), confusion over labels ("best before" and "use by"), and poor in-home storage.

Figure 1.Food loss and food waste occur at every stage of the supply chain

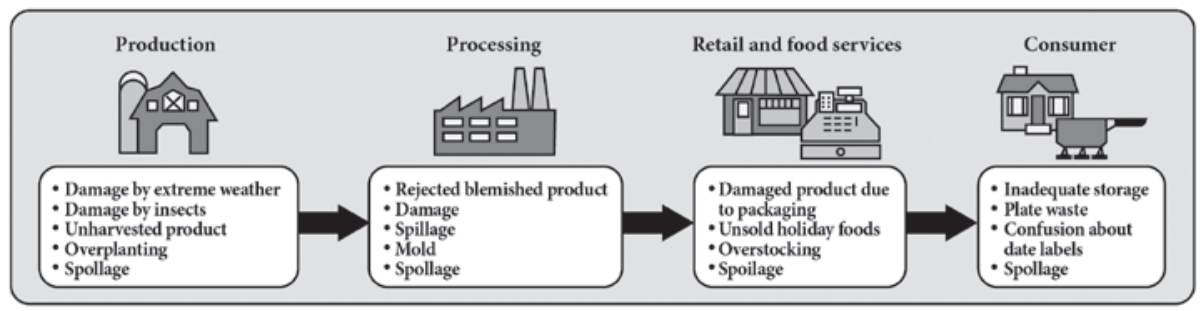

The amount of food that is thrown away every day is large, as shown by the data of the $\mathrm{FAO}^{9}$. According to their estimates, about 1.3 billion tons of food destined for human consumption is wasted or thrown away every year. In other words, about one-third of the food destined for human consumption perishes or is thrown away each year. This points to the fact that every year, in addition to food, large amounts of all resources used in food production are lost. As already mentioned, food losses, as well as food waste, can occur at any stage of the supply chain, from agricultural production to final consumption. In the developed countries of the world, most food is thrown at the end of the supply chain, ie. at the stage of final consumption. On the other hand, in developing countries, food losses and food waste occur most in the initial stages of the supply chain.

9 FAO (2011) Global food losses and food waste - Extent, causes and prevention, Rome. Available online at: http://www.fao.org/3/mb060e/mb060e00.htm (accessed 10 September 2021). 


\subsection{GENERATION OF FOOD WASTE IN THE PRODUCTION PROCESS}

Primary production refers to the first step in the supply chain of food products and includes activities that take place on farms. After the growth or cultivation phase, and the harvesting or slaughter phase, the product enters the pre-processing phase and then the processing. Defining whether a particular operation belongs to the pre-processing phase, or the processing phase is not always easy. The reason for this lies in the fact that certain activities on the products are carried out immediately in the field, for example, the separation of the outer leaves or roots from the vegetables. Such activities that change the product, but do not change the basic characteristics of the product, can be included in the pre-processing phase. ${ }^{10}$

In primary production, food losses can be divided into four categories:11 (1) production-related food losses - losses due to the action of diseases, pests, and weather conditions, (2) economic causes of food losses - implies a situation when market prices at the time of harvest or harvest of agricultural products are too low, so producers decided to leave part of the crop in the field because they cannot cover production costs, (3) food losses due to commercial imperfection of products - losses that occur due to the fact that the products do not meet the minimum quality standards in terms of appearance, shape, color, maturity, etc. and (4) food losses due to increased production - refers to a situation where farmers increase production in order to reduce losses that may occur due to the effects of weather, pests or because they predict high market prices. In a situation when the year is favorable, ie when there are no weather troubles or pests, overproduction can occur. Then the agricultural land is plowed again, and the agricultural production is returned to the soil as organic matter. This does not represent a complete loss, but it represents a loss in terms of the reduction of food products as well as a loss of resources spent on the production of these agricultural products. In addition to the listed causes of food losses in the production process, there are some other causes of food losses and waste, and they relate to the food of animal origin. The increase in food waste can be affected by the death of the animal during transport to the slaughterhouse, animal disease, such as milking cows, damage to fish during fishing, and the like.

10 FUSIONS (2016) Food waste quantification manual to monitor food waste amounts and progression. Reducing food waste through social innovation. Paris. Available online at: https:// www.eu-fusions.org/phocadownload/Publications/FUSIONS\%20Food\%20Waste\%20Quantification\%20Manual.pdf (accessed 10 September 2021).

11 FAO (2014) Background paper on the economics of food loss and waste. Rome. Available online at: http://www.fao.org/3/a-at143e.pdf (accessed 10 September 2021). 
Food losses and waste in the production process are more of a problem in poorer countries and developing countries than in developed countries. One of the main reasons for this is poor mechanization equipment and technology or lack of it, which is required when harvesting, lack of infrastructure and storage, and poor refrigeration and processing equipment. ${ }^{12}$ Also, food losses due to premature harvests or harvests often occur in developing countries. Due to food shortages or lack of money, farmers decide to harvest before agricultural products ripen. This leads to losses in both nutritional and economic value. ${ }^{13}$

\subsection{GENERATION OF FOOD WASTE IN THE DISTRIBUTION PROCESS}

Food waste is generated at every stage of the supply chain, including the process of food distribution from producers or processors to retailers. There are many reasons why food losses occur during distribution. By increasing the length of the supply chain, product damage and food waste are more likely to occur. As a result of increasing the length of the supply chain, operating costs also increase. ${ }^{14}$

The main reasons for food losses in the distribution process mentioned in the literature relate to product damage during transport, handling, and storage of products. In addition, the impact of poor temperature conditions during transport, which affect the development of bacteria and microbes, and ultimately the formation of food waste. The already mentioned long supply chains during which frequent handling of food products occurs also have an impact on increasing food waste. On average, a food supply chain is handled 33 times before a consumer touches a product in a store. Food losses also occur during the storage of products due to the action of parasites and pests. In addition, during storage of certain food products, the process of germination occurs, i.e., losses in weight or volume of the product due to too long storage or inadequate packaging $^{15}$.

12 FAO (2018) Gender and food loss in sustainable food value chains, Rome. Available online at: http://www.fao.org/3/I8620EN/i8620en.pdf (accessed 10 September 2021).

13 FAO (2011) Global food losses and food waste - Extent, causes and prevention, Rome. Available online at: http://www.fao.org/3/mb060e/mb060e00.htm (accessed 10 September 2021).

14 Verghese, K., Lewis, H., Lockrey, S., Williams, H. (2013)The role of packaging in minimising food waste in the supply chain of the future. Centre for Design; RMIT University. Available online at: https://www.rmit.edu.au/content/dam/rmit/documents/research/centres/cwhsr/publications/Report-the-role-packaging-in-minimising-food-waste-in-the-supply-chain-of-the-future.pdf (accessed 10 September 2021).

15 Kantor, LS., Lipton K., Manchester, A., Oliveira V.: Estimating and addressing America's food losses. Food Review/National Food Review, 20 (1) 1997, p. 4. 
It often happens in practice that store management sets standards regarding the appearance of food products when taking them from suppliers. If the products have minor visual defects or minor damage, and the quality of the products is still unchanged, stores will generally not pick up the products. Such a situation is common when delivering fresh fruits and vegetables that are subject to rapid spoilage. It is estimated that in the UK, $20 \%$ to $40 \%$ of fruit and vegetables are thrown away before they reach the store because they do not meet the visual standards of the product. In addition to fruits and vegetables, the fishing industry also contributes to the increase in food waste due to the unsatisfactory appearance of fish required by stores. ${ }^{16}$

\subsection{GENERATION OF FOOD WASTE IN THE RETAIL}

FAO, 2011: 26) states that in the wholesale and retail sector in Europe (including Russia) in 2009 most food waste was generated in the category "fruits and vegetables" (10\%) and category "fish and seafood" (9\%). The least food waste was generated in the category "oilseeds and legumes" (1\%), and the category "milk and dairy products" $(0.5 \%) .{ }^{17}$

Just as at every stage of the supply chain, there are reasons that cause food waste to occur, so at the retail stage, there are a number of reasons that affect the increase in food waste. Lukic et al. ${ }^{18}$ in their paper present several causes of food losses in the retail sector. They believe that the main causes of food losses in retail are lack of knowledge, oversized orders, inadequate storage, labeling, packaging, handling and inventory management, and insufficient product quality. Furthermore, Bellù ${ }^{19}$ also points out the over-ordering of products as one of the main reasons for the generation of food waste in retail stores. As customers are becoming more demanding every day, stores strive to offer the widest and deepest range of products in their offer. Such a practice in most cases leads to the accumulation of stocks in warehouses store, which further increases the risk of food waste. As another significant reason for the generation of food waste, he cites the fact that many retail companies do not want to

16 Racz, A., Vasiljev Marchesi, V., Crnković, I.: Economical, Environmental and Ethical Impact of Food Wastage in Hospitality and Other Global Industries, JAHR: Europski časopis za bioetiku, 9 (1) 2018, pp. 25-42.

17 FAO (2011) Global food losses and food waste - Extent, causes and prevention, Rome. Available online at: http://www.fao.org/3/mb060e/mb060e00.htm (accessed 10 September 2021).

18 Lukic, R., Vojteski Kljenak D., Jovancevic D.: Retail food waste management, Management research and practice, 6 (4) 2014, p. 29.

19 Bellù, L.G. (2017) Food losses and waste: issues and policy options. Rome, FAO. Available online at: https://www.fao.org/3/CA1431EN/ca1431en.pdf (accessed 10 September 2021). 
sell products to customers if the quality of the product is reduced. The reason why retail companies apply such an attitude in their business is that they do not want to damage their reputation gained in the market or do not want to endanger the health of their customers.

In addition to the insufficient level of product quality, as one of the main reasons for the generation of food waste in retail, Verghese et al. ${ }^{20}$ point out two other reasons that affect the generation of food waste in retail. The first reason relates to overcrowded shelves, mostly fresh produce like fruits and vegetables. In this case, there is damage to those products that are at the bottom of the shelf, and once the product is damaged, it is more likely that customers will not buy it and will end up in the trash. As another reason that affects the generation of food waste in retail, they cite poor organizational skills of retailers. In other words, it is inadequate inventory management by staff in such a way that products with a shorter shelf life are not the first to be displayed on the shelf. Thus, if an expiring product is thrown on the shelf behind products that have a longer shelf life, or if such a product is not displayed on the shelf at all, it is more likely to end up as a waste over time.

EuroCommerce, a European organization representing the wholesale and retail sector, also sets out the reasons that affect the generation of food waste in retail. In addition to the already mentioned oversized orders, seasonal fluctuations in the offer of fresh food products, oversized packaging, and consumer misunderstanding of the expiration date with the labels "use by" and "best use by" ${ }^{21}$ stand out. According to the above, it is clear that retailers face many challenges in terms of preventing food waste. In order to succeed in this, it is necessary to establish cooperation with all members of the supply chain. Therefore, EuroCommerce ${ }^{22}$ outlines the ways in which retailers act to prevent food waste: (1) they guarantee food producers that they will buy the entire crop, (2) they are organizing faster delivery to make the most of the product's shelf life, (3) they offer new promotional offers like "buy one, get another later for free" and (4) they donate the food surplus.

\footnotetext{
20 Verghese, K., Lewis, H., Lockrey, S., Williams, H. (2013) The role of packaging in minimising food waste in the supply chain of the future. Centre for Design; RMIT University. Available online at: https://www.rmit.edu.au/content/dam/rmit/documents/research/centres/cwhsr/publications/Report-the-role-packaging-in-minimising-food-waste-in-the-supply-chain-of-the-future.pdf (accessed 10 September 2021).p. 17

${ }^{21}$ EuroCommerce (2017) Rising to the food waste challenge. Available online at: https:// www.eurocommerce.eu/media/134575/Food\%20Waste\%20Brochure\%20-\%20final.pdf (accessed 10 September 2021).

22 EuroCommerce (2017) Rising to the food waste challenge. Available online at: https:// www.eurocommerce.eu/media/134575/Food\%20Waste\%20Brochure\%20-\%20final.pdf (accessed 10 September 2021).
} 


\subsection{GENERATION OF FOOD WASTE DURING FINAL CONSUMPTION}

Food waste in the final consumption phase, which is also the last phase of the food supply chain, implies food waste incurred by end-users in households or businesses such as restaurants or restaurants. Therefore, food waste in the final consumption phase includes edible food products that are discarded due to reduced quality, food that is bought but not prepared for eating, and food that is prepared for eating but not consumed. ${ }^{23}$ Most food waste along the entire food supply chain is generated at the final consumption stage. Consequently, the cost of food waste is highest in the final consumption phase, i.e., in the household sector. Observing food waste in the final consumption phase within the developed countries, significantly more food waste is generated in developed countries around the world (28\%), than in developing countries (7\%). Thus, most food waste in the final consumption phase is generated in North America and Oceania, Europe, and East Asia. ${ }^{24}$

According to WRAP ${ }^{25}$, the United Kingdom generates around 7.05 million tons of food waste per year in the household sector or about 108 kilograms of food waste per person. The total cost of food waste in the household sector in the United Kingdom in 2015 was $£ 14.9$ billion, or $£ 229$ per person. Furthermore, in the United States (USA), about 27 million tons of food waste are generated annually in the household sector or as much as $43 \%$. The total cost of food waste in the household sector, in the US, is $\$ 144$ billion. ${ }^{26}$ The largest amount of food waste is surplus prepared food at home, bakery products, fresh vegetables, and dairy products. Household income has been found to play an important role in the amount of food waste. Thus, households with higher incomes buy a smaller amount of higher quality food products, while households with lower incomes buy a larger amount of lower quality food products. Therefore, households with higher incomes generate less food waste than those

23 Lipinski, B., Hanson, C., Lomax, J., Kitinoja, L., Waite, R., Searchinger, T. (2013) Reducing food loss and waste. Working paper of World Resources Institute. Washington, DC. Available online at: https://www.wri.org/publication/reducing-food-loss-and-waste (accessed 10 September 2021).

24 Gustavsson, J., Cederberg, C., Sonesson, U., van Otterdijk, R., Meybeck, A. (2011) Global food losses and food waste- Extent, causes and prevention. Dusseldorf: Food and Agriculture organization of the United Nations

25 WRAP (2017) Household Food and Drink Waste in the UK. Available online at: http:// www.wrap.org.uk/sites/files/wrap/Household_food_and_drink_waste_in_the_UK_-_report. pdf (accessed 10 September 2021).

26 ReFED (2016) A Roadmap to Reduce U.S. Food Waste by 20 Percent. Available online at: https://www.refed.com/downloads/ReFED_Report_2016.pdf (accessed 10 September 2021). 
households with lower incomes. Also, often households with higher incomes cook less, which results in smaller amounts of discarded food.

In order to successfully reduce the generation of food waste in the final consumption phase, it is necessary to consider the behavior of consumers during the food supply process. The food supply process consists of five steps. The first step concerns the procurement of food products. The second step involves the preparation of purchased food products and includes the processes of chopping, peeling, blanching, etc. Then follows the third step, which relates to the procedures of cooking and baking food products. The fourth step involves the consumption of a prepared meal, while the fifth step refers to the procedures of food disposal, ie the freezing of excess food and the disposal of leftover food. ${ }^{27}$ Food rejection can occur at all steps during the food supply process.

The reasons for the generation of food waste in the final consumption phase are many. For example, some of the reasons may be too much food bought, too much food being prepared for a particular meal, too short a shelf life, a lack of understanding of labeling the shelf life with the terms "use by" and "best used by". Several authors have contributed to the research of food waste generation in the final consumption phase in order to determine the attitudes of green consumers towards food waste, the reasons for the generation of food waste, and to determine policies that would help reduce the generation of food waste.

\section{STATE-OF-THE-ART: FOOD WASTE RESEARCH IN THE RETAIL SUPPLY CHAIN}

Food waste generally refers to food discarded downstream in the supply chain resulting from retailers and consumers behavior. Over $60 \%$ of Europeans see measures to reduce food waste as a responsibility of retailers. Retailers have been identified as one of the most important actors who contribute to changes in consumer consumption patterns. ${ }^{28}$

Retailers and related distribution channels have been addressed less often in empirical research than other members of the supply chain (SC) with concerning food waste, which is interesting, as they face challenges connected with

27 Boom, I.F.A. (2016) Such a waste, household food waste. Bachelor thesis. Wageningen University \& Research. Available online at: https://edepot.wur.nl/385502 (accessed 10 September 2021).

28 Lehner, M.: Translating sustainability: the role of the retail store, International Journal of Retail \& Distribution Management, 43(4/5) 2015, pp. 386-402. 
the reduction of food waste in their operations. ${ }^{29}$ However, although the retail focus has long been neglected ${ }^{30}$, it is gaining momentum. ${ }^{31}$

Literature review on the retail-related food waste literature puts focus on the information sharing among different supply chain members ${ }^{32}$, re-distribution strategies, charities, and social supermarkets ${ }^{33}$, reuse and recycling techniques and measures ${ }^{34}$. Retail-focused research primarily investigates the quantitative dimension of food loss through volume measurement at the store level ${ }^{35}$, the carbon footprint of food waste ${ }^{36}$, packaging waste ${ }^{37}$. The food waste in different supply chain phases has been estimated in many studies, providing somewhat different results, depending on the measures and methods used, but the studies seem to agree that product groups such as fresh bakery products and fresh fruits and vegetables contribute most to the avoidable food waste, and are most significant in affecting the total turnover in all parts of the

distribution chain. ${ }^{38}$ The food and vegetable segment are of utmost importance to the EU, as its production accounts to close $14 \%$ of the total EU agricultural output, by using only $3 \%$ of the EU's cultivated area (EC, 2019). The sector involves about 1.4 million farm holdings, mostly small, with a total chain turnover of $€ 150$ billion. Due to product perishability, but also the variety of the EU's produce, the internal trade flows predominate over extra-EU trade seen

29 Askew, K. (2018) What trends will shape grocery retail in 2018? FoodNavigator. Available online at: https://www.foodnavigator.com/Article/2017/12/18/What-trendswill-shape-groceryretail-in-2018 (accessed 10 September 2021).

30 Cicatiello, C., Franco, S., Pancino, B., \& Blasi, E.: The value offood waste: An exploratory study on retailing, Journal of Retailing and Consumer Services, 30 2016, pp. 96-104.

31 Giuseppe, A., E. Mario and M. Cinzia: Economic benefits from food recovery at the retail stage: An application to Italian food chains, Waste Management, 34 (7) 2014, pp. 1306-1316.

32 Papargyropoulou, E., Lozano, R., K. Steinberger, J., Wright, N., Ujang, Z. Bin: The food waste hierarchy as a framework for the management of food surplus and food waste, Journal of Cleaner Production, 76 (August) 2014, pp. 106-115.

33 Teller, C., Holweg, C., Reiner, G., Kotzab, H.: Retail store operations and food waste, Journal of Cleaner Production, 185 2018, pp. 981-997.

34 Dias, K. T., \& Braga Junior, S. S.: The use of reverse logistics for waste management in a Brazilian grocery retailer, Waste Management \& Research, 34(1) 2016, pp. 22-29.

35 Cicatiello, C., Franco, S., Pancino, B., \& Blasi, E.: The value of food waste: An exploratory study on retailing, Journal of Retailing and Consumer Services, 30 2016, pp. 96-104.

36 Scholz, K., Eriksson, M., Strid, I.: Carbon footprint of supermarket food waste, Resources, Conservation and Recycling, 94 (January), 2015, pp. 56-65.

37 Fernie, J., Hart, C.: UK packaging waste legislation, British Food Journal, 103 (3) 2001, pp. 187-197.

38 Mena, C.; Adenso-Diaz, B.; Yurt, O.: The causes of food waste in the supplier-retailer interface: Evidences from the UK and Spain, Resources, Conservation and Recycling, 55 (6) 2011, pp. 648-658. 
in other sectors. As gatekeeper to the food supply chain, the retail and wholesale sector is a crucial factor in the pursuit of minimizing food waste ${ }^{39}$

In addition to a small number of retail studies, more attention should be put on managerial attitudes and approaches to food waste mitigation in the food retail supply chain.

\section{CONCLUSION}

The goal of all actors in the food supply chain is to ensure and maintain the highest possible product quality through all phases of the supply chain. In order to achieve this, it is necessary to ensure appropriate conditions for storage and preservation of food, since food products belong to the group of sensitive products. Given that around 1.3 billion tons of food waste are generated annually worldwide, measures need to be taken to reduce food losses and waste along the entire supply chain.

In the production phase, food losses occur due to the effects of diseases, pests, and weather conditions. In addition, food losses at this stage occur due to economic reasons in situations where market food prices are too low, commercial product imperfections, and overproduction. In the distribution phase, food waste is generated during transport, inadequate handling, and inadequate temperature conditions during storage. Furthermore, in retail, food waste occurs for several reasons. The first reason is related to suppliers, and it implies situations in which the quality of the product has already been impaired during delivery or the product has expired. The second reason is related to the operation of the retail company and relates to lack of knowledge and motivation of sales staff, the creation of excessive stocks in stores, careless handling of products, etc. The third reason is related to customers and their undesirable behavior when buying and high demands especially look fresh products like fruits and vegetables. In the final consumption phase, the most common reason leading to food waste relates to an excessive amount of purchased and prepared food that is not later used and ends up as waste. In addition, a common reason that leads to the formation of food waste at this stage is the purchase of food products whose expiration date is at the expiration date. Furthermore, consumers often do not understand the difference between "use by" and "best use by" labels, so food often ends up as waste even though it was safe to consume. Therefore, educating consumers as well as taking preventive measures to reduce food waste especially at the retail level is necessary in order to contribute

39 Gruber, V., Holweg, C., \& Teller, C.: What a Waste! Exploring the Human Reality of Food Waste from the Store Manager's Perspective, Journal of Public Policy \& Marketing, 35 (1) 2016, pp. 3-25. 
to reducing food waste, not only in the final consumption phase but also in the retail phase and ensuring significant impact and contribution for the European Green Deal, as well as Farm to Fork Strategy.

\section{LITERATURE}

1. Alexandratos, N., Bruinsma, J. (2012) WORLD AGRICULTURE TOWARDS 2030/2050 - The 2020 Revision, Available at: http://www.fao.org/3/a-ap106e.pdf (accessed 10 September 2021).

2. Askew, K. (2018) What trends will shape grocery retail in 2018? FoodNavigator. Available online at: https://www.foodnavigator.com/Article/2017/12/18/Whattrendswill-shape-grocery-retail-in-2018 (accessed 10 September 2021).

3. Bellù, L.G. (2017) Food losses and waste: issues and policy options. Rome, FAO. Available online at: https://www.fao.org/3/CA1431EN/ca1431en.pdf (accessed 10 September 2021).

4. Boom, I.F.A. (2016) Such a waste, household food waste. Bachelor thesis. Wageningen University \& Research. Available online at: https://edepot.wur.nl/385502 (accessed 10 September 2021).

5. Cicatiello, C., Franco, S., Pancino, B., \& Blasi, E.: The value of food waste: An exploratory study on retailing, Journal of Retailing and Consumer Services, 30 2016, pp. 96-104.

- DOI: https://doi.org/10.1016/j.jretconser.2016.01.004

6. Derqui, B., Fayos, T., Fernandez, V.: Towards a More Sustainable Food Supply Chain: Opening up Invisible Waste in Food Service, Sustainability, 8 (7) 2016, pp. 1-20.

- DOI: https://doi.org/10.3390/su8070693

7. Dias, K. T., \& Braga Junior, S. S.: The use of reverse logistics for waste management in a Brazilian grocery retailer, Waste Management \& Research, 34(1) 2016, pp. 22-29.

- DOI: https://doi.org/10.1177/0734242X15615696

8. EuroCommerce (2017) Rising to the food waste challenge. Available online at: https://www.eurocommerce.eu/media/134575/Food\%20Waste\%20Brochure $\% 20$ -\%20final.pdf (accessed 10 September 2021).

9. European Green Deal (2019) Available online at: https://ec.europa.eu/info/strategy/priorities-2019-2024/european-green-deal/delivering-european-green-deal_ en (accessed 10 September 2021).

10. FAO (2011) Global food losses and food waste - Extent, causes and prevention, Rome. Available online at: http://www.fao.org/3/mb060e/mb060e00.htm (accessed 10 September 2021). 
11. FAO (2014) Background paper on the economics of food loss and waste. Rome. Available online at: http://www.fao.org/3/a-at143e.pdf (accessed 10 September 2021).

12. FAO (2014) Food balance sheets. Available at: http://faostat3.fao.org/faostatgateway/go/to/download/FB/*/E (accessed 10 September 2021).

13. FAO (2018) Gender and food loss in sustainable food value chains, Rome. Available online at: http://www.fao.org/3/I8620EN/i8620en.pdf (accessed 10 September 2021).

14. Farm to Fork Strategy (2019) Available online at: https://ec.europa.eu/food/horizontal-topics/farm-fork-strategy_en (accessed 10 September 2021).

15. Fernie, J., Hart, C.: UK packaging waste legislation, British Food Journal, 103 (3) 2001, pp. 187-197.

- DOI: https://doi.org/10.1108/00070700110386737

16. FUSIONS (2016) Food waste quantification manual to monitor food waste amounts and progression. Reducing food waste through social innovation. Paris. Available online at: https://www.eu-fusions.org/phocadownload/Publications/ FUSIONS\%20Food\%20Waste\%20Quantification\%20Manual.pdf (accessed 10 September 2021).

17. Giuseppe, A., E. Mario and M. Cinzia: Economic benefits from food recovery at the retail stage: An application to Italian food chains, Waste Management, 34 (7) 2014, pp. 1306-1316.

- DOI: https://doi.org/10.1016/j.wasman.2014.02.018

18. Gruber, V., Holweg, C., \& Teller, C.: What a Waste! Exploring the Human Reality of Food Waste from the Store Manager's Perspective, Journal of Public Policy \& Marketing, 35 (1) 2016, pp. 3-25.

- DOI: https://doi.org/10.1509/jppm.14.095

19. Gustavsson, J., Cederberg, C., Sonesson, U., van Otterdijk, R., Meybeck, A. (2011) Global food losses and food waste- Extent, causes and prevention. Dusseldorf: Food and Agriculture organization of the United Nations

20. Kantor, LS., Lipton K., Manchester, A., Oliveira V.: Estimating and addressing America's food losses. Food Review/National Food Review, 20 (1) 1997, pp. 2-12.

21. Lehner, M.: Translating sustainability: the role of the retail store, International Journal of Retail \& Distribution Management, 43(4/5) 2015, pp. 386-402.

- DOI: https://doi.org/10.1108/IJRDM-02-2014-0013

22. Lipinski, B., Hanson, C., Lomax, J., Kitinoja, L., Waite, R., Searchinger, T. (2013) Reducing food loss and waste. Working paper of World Resources Institute. Washington, DC. Available online at: https://www.wri.org/publication/reducingfood-loss-and-waste (accessed 10 September 2021).

23. Lukic, R., Vojteski Kljenak D., Jovancevic D.: Retail food waste management, Management research and practice, 6 (4) 2014, pp. 23-39. 
24. Mena, C.; Adenso-Diaz, B.; Yurt, O.: The causes of food waste in the supplier-retailer interface: Evidences from the UK and Spain, Resources, Conservation and Recycling, 55 (6) 2011, pp. 648-658.

- DOI: https://doi.org/10.1016/j.resconrec.2010.09.006

25. Papargyropoulou, E., Lozano, R., K. Steinberger, J., Wright, N., Ujang, Z. Bin: The food waste hierarchy as a framework for the management of food surplus and food waste, Journal of Cleaner Production, 76 (August) 2014, pp. 106-115.

- DOI: https://doi.org/10.1016/j.jclepro.2014.04.020

26. Racz, A., Vasiljev Marchesi, V., Crnković, I.: Economical, Environmental and Ethical Impact of Food Wastage in Hospitality and Other Global Industries, JAHR: Europski časopis za bioetiku, 9 (1) 2018, pp. 25-42.

- DOI: https://doi.org/10.21860/j.9.1.1

27. ReFED (2016) A Roadmap to Reduce U.S. Food Waste by 20 Percent. Available online at: https://www.refed.com/downloads/ReFED_Report_2016.pdf (accessed 10 September 2021).

28. Scherhaufer, S., Moates, G., Hartikainen, H., Waldron, K., Obersteiner, G.: Environmental impacts of food waste in Europe, Waste Management, 77 (July) 2018, pp. 98-113.

- DOI: https://doi.org/10.1016/j.wasman.2018.04.038

29. Scholz, K., Eriksson, M., Strid, I.: Carbon footprint of supermarket food waste, Resources, Conservation and Recycling, 94 (January) 2015 pp. 56-65.

- DOI: https://doi.org/10.1016/j.resconrec.2014.11.016

30. Teller, C., Holweg, C., Reiner, G., Kotzab, H.: Retail store operations and food waste, Journal of Cleaner Production, 185 2018, pp. 981-997.

- DOI: https://doi.org/10.1016/j.jclepro.2018.02.280

31. UNEP (2015) Sustainable Development Goals. Available online at: http://www. undp. org/content/dam/undp/library/corporate/brochure/SDGs_Booklet_Web_ En.pdf, (accessed 10 September 2021).

32. Vanham, D., Bouraoui, F., Leip, A., Grizzetti, B., Bidoglio, G.: Lost water and nitrogen resources due to EU consumer food waste, Environmental Research Letters, 10 (8) 2015, pp. 1-15.

- DOI: https://doi.org/10.1088/1748-9326/10/8/084008

33. Verghese, K., Lewis, H., Lockrey, S., Williams, H. (2013)The role of packaging in minimising food waste in the supply chain of the future. Centre for Design; RMIT University. Available online at:

34. https://www.rmit.edu.au/content/dam/rmit/documents/research/centres/cwhsr/ publications/Report-the-role-packaging-in-minimising-food-waste-in-the-supply-chain-of-the-future.pdf (accessed 10 September 2021).

35. WRAP (2017) Household Food and Drink Waste in the UK. Available online at: http://www.wrap.org.uk/sites/files/wrap/Household_food_and_drink_waste_in_ the_UK_-_report.pdf (accessed 10 September 2021). 